\title{
Effect of Thymoquinone against Aluminum Chloride-Induced Alzheimer-Like Model in Rats: A Neurophysiological and Behavioral Study
}

\author{
MOHAMED A.F. ZAHER, M.Sc. ${ }^{\mathbf{~}}$ MOHAMED A. BENDARY, M.D. ${ }^{\mathbf{1 , 2}}$ and AHMED S. ALY, M.D. ${ }^{\mathbf{3 , 4}}$ \\ The Department of Physiology, Faculty of Medicine, King Abdull Aziz University, Jeddah, Saudi Arabia ${ }^{1}$ and \\ Menoufia University, Egypt ${ }^{2}$, The Department of Pharmacology, Faculty of Medicine, King Abdull Aziz University, \\ Jeddah, Saudi Arabia ${ }^{3}$ and Assuit University, Egypt ${ }^{4}$
}

\begin{abstract}
Background: Alzheimer Disease (AD) is a progressive neurodegenerative disorder characterized by oxidative stress, neuro-inflammation and synaptic dysfunction, which caused in part by abnormal aggregation of senile plaques and neurofibrillary tangles outside and inside the cerebral neurons, respectively. Thymoquinone (TQ) is the major bioactive ingredient of the volatile oil of Nigella sativa seed and it possess anti-inflammatory and antioxidant effects in some neuronal diseases.
\end{abstract}

Aim of Study: To evaluate the neuroprotective potential of TQ on the oxidative stress status of the brain in aluminum chloride $(\mathrm{AlCl} 3)$-induced $\mathrm{AD}$ in rats.

Material and Methods: Thirty adult male Sprague Dawley albino rats were used in this study. They were randomly divided into 3 groups. Group 1 (control group). Group 2 (AD group): Supplemented orally with $\mathrm{AlCl} 3(17 \mathrm{mg} / \mathrm{kg} /$ day $)$ for 4 weeks. Group 3 (TQ/AD group) supplemented concomitantly with oral TQ $(10 \mathrm{mg} / \mathrm{kg} /$ day $)$ and $\mathrm{AlCl} 3(17 \mathrm{mg} / \mathrm{kg} /$ day $)$ for 4 weeks. At the end of the experiment, spatial working memory was assessed using the Y-maze spontaneous alternation test. Then, serum levels of Malondialdehyde (MDA) and Glutathione Peroxidase Enzyme (GPX) were assessed. Then, the rats were sacrificed and the brain tissue homogenate content of tau protein, AR and acetyle choline were determined.

Results: In AD group, spatial working memory was impaired as indicated by a significant decline of Spontaneous Alteration Performance (SAP\%) at Y-maze behavior test. Also, $A R$, tau protein, acetyle choline in brain and serum MDA were significantly increased with a significant decrease of serum GPX. Co-administration of TQ with $\mathrm{AlCl} 3$ in TQ/AD group, significantly decreased $A R$, tau protein, acetyle choline in brain and serum MDA and increased (SAP\%) and serum GPX.

Conclusion: TQ could mitigate the neurodegenerative markers and oxidative stress indices encountered in AD, presumably via its antioxidant and anti-inflammatory effects.

Correspondence to: Dr. Mohamed A.F. Zaher, The Department of Physiology, Faculty of Medicine, King Abdull Aziz University, Jeddah, Saudi Arabia
This may implement TQ as an adjuvant alternative medical strategy in ameliorating this devastating disease.

$\begin{aligned} \text { Key Words: } & \text { AlCl3 - Alzheimer disease }- \text { Thymoquinone }-Y \text { - } \\ & \text { maze - Tau protein - A P - Acetyle choline - } \\ & \text { Oxidative stress. }\end{aligned}$

\section{Introduction}

ALZHEIMER Disease (AD) is a progressive neurodegenerative disorder affecting mostly the elderly individuals with a profound decline in cognitive function and cumulative neurophysiatric changes including alterations in mood and behavior in conjunction with memory impairment $[\mathbf{1 , 2}]$. AD is the most common cause of dementia, where it accounts for up to $70 \%$ of all cases of dementia [3]. The term AD was first adopted by the German psychiatrist Alois Alzheimer who has described this disease in 1906 [4].

Epidemiologically, AD is one of the major health challenges whose global prevalence has increased during recent years. Worldwide, about 44 million individuals had AD in 2015 and this figure is expected to be doubled by 2050 [2]. It has been documented that among individuals over 65 years of age, approximately $1 \%$ have AD and among those over 85 years of age, the prevalence of the disease is close to $4 \%$ [5].

$\mathrm{AD}$ is characterized clinically by progressive intellectual decline with impairment of short-term memory which is the first clinical feature of the disease due to degeneration of the hippocampal and cortical neurons. With progression of the disease, the long-term memory is also affected with more cognitive disabilities [6]. 
Actually, AD is a multifactorial disease, with several modifiable and non-modifiable risk factors accused for its development and progression. Age is the greatest risk factor for the development of this disease, where the likelihood of developing AD increases exponentially with age, approximately doubling every five years after age 65 [7].

The exact mechanism(s) of AD has not been fully elucidated yet, however, it has been theorized that the neuronal loss, especially of the cholinergic neurons and of the neuronal synapses described in $\mathrm{AD}$ is related to the deposition of abnormal proteins in the cerebral cortex and other brain areas. These abnormal proteins include insoluble amyloid beta $(\mathrm{A} \beta)$ proteins deposited outside the cerebral neurons forming extracellular "senile plaques" and the microtubules-associated protein (tau protein) which becomes highly phosphorylated and hence aggregated inside the neurons forming intracellular "Neurofibrillary Tangles" (NFTs). These senile plaques and NFTs are considered two major hallmark pathological lesions of AD [8]. The disease is characterized pathologicallyby oxidative stress, neuro-inflammation and synaptic dysfunction, which may be caused in part by abnormal aggregation of senile plaques and NFTs, causing deleterious synaptic and neuronal loss which often begins several years prior to memory loss [8].

Although the basic research in $\mathrm{AD}$ has made remarkable progress in the past two decades, the currently available drugs like donepezil, rivastigmine, galantamine and memantine are able only to improve cognitive symptoms temporarily, and no treatment can reverse, stop, or even slow the inexorable neurodegenerative process. These synthetic drugs are associated with a number of side effects, possess much economic burden and are not implemented for all cases of AD [9].

Therefore, there is a high demand for discovering new remedies of natural origin obtained from medicinal plants to be directed for protection, slowing down or halting $\mathrm{AD}$ disease progression in its early stages. In that context, Thymoquinone (TQ) which is the major bioactive ingredient and constituent of the volatile oil of Nigella sativa seed was tried in this study [10].

TQ has anti-inflammatory and antioxidant effects in some neuronal diseases [11,12]. In addition, it is reported to have protective effects against $A \beta$ induced toxicity in neuronal cells [13]. In light of this knowledge, the present study was designed to evaluate the neuroprotective potential of TQ on the oxidative stress status of the brain in aluminum chloride-induced $\mathrm{AD}$ in rats.

\section{Material and Methods}

This study wad done at King Fahd Medical Research Center (KFMRC), King Abdull Aziz University, Jeddah Saudi Arabia, April 2018-June 2019.

\section{Chemicals:}

$\mathrm{AlCl} 3$ (MW=133.34) was purchased as powder from Sigma-Aldrich Co. Munich, Germany) and was dissolved in distilled water.

TQ (solid crystals purity 99\%) was purchased from Sigma-Aldrich Co., Darmstadt, Germany) was dissolved in corn oil as a final concentration of $20 \mathrm{mg} / \mathrm{ml}(\mathrm{w} / \mathrm{v})$.

\section{Animals:}

Thirty adult male Sprague Dawley albino rats of approximately $250 \pm 25$ gram Body Weight (BW) were used in this study. The rats were obtained from the Animal House of King Fahd Medical Research Center (KFMRC), Jeddah, Saudi Arabia. The rats were left to acclimatize without handling for one week prior to the start of the experiments. The animals were housed in well-ventilated cages at a temperature of $23 \pm 2 \mathrm{C}^{\circ}$, under the natural 12 hour day/night cycle with free access to a standard commercial rodent chaw and water ad libitum throughout the whole study period. The experimental protocol of this study was revised and approved by the local ethical guidelines established by the Unit of Biomedical Ethics Research Committee (REC), Faculty of Medicine, King Abdulaziz University, Saudi Arabia (reference NO; 452-16, 2017), in accordance with the international guiding principles for the care and use of the research animals.

\section{Experimental groups:}

The rats were weighted and randomly allocated into 3 groups of 10 rats each:

- Group 1 (Control group): The rats of this group were orally administered via gastric gavage with $1 \mathrm{ml} / \mathrm{kg} /$ day of corn oil (the vehicle of TQ) for 4 weeks.

- Group 2 (AD group): In this group, Alzheimer'slike rat model was experimentally induced by oral administration of $\mathrm{AlCl} 3(17 \mathrm{mg} / \mathrm{kg} /$ day $)$ dissolved in distilled water for 4 weeks $[14,15]$. It is to be noted that the chosen dose of $\mathrm{AlCl} 3$ in this study was reported to be the minimal dose producing a detrimental biological effect on the tissues of rodents in short term use [16] .

- Group 3: (TQ/AD group): The rats of this group were supplemented concomitantly with both oral TQ at a dose of $10 \mathrm{mg} / \mathrm{kg} /$ day dissolved in corn 
oil and oral $\mathrm{AlCl} 3(17 \mathrm{mg} / \mathrm{kg} /$ day $)$ dissolved in distilled water for 4 weeks.

\section{Induction of experimental $A D$ :}

In this study, AD-like model was induced by oral administration of $\mathrm{AlCl} 3$ dissolved in distilled water $(17 \mathrm{mg} / \mathrm{kg} /$ day $)$ for 4 weeks [15]. The development of AD like state was considered when the spatial recognition and working memory was impaired upon eliciting the $\mathrm{Y}$ maze cognitive test [17].

\section{Experimental protocol:}

At the end of time schedule of the experimental design and following an overnight fasting, blood samples were withdrawn from the retro-orbital venous sinuses in non-heparinized Ependorf tubes. The blood samples were left to clot in a water bath at room temperature, followed by their centrifugation at 3000r.p.m for 15 minutes. The clear supernatant serum was separated, frozen and stored at $-20^{\circ} \mathrm{C}$ till further biochemical analysis of serum malondialdehyde (MDA, as a marker of lipid peroxidation and oxidative stress) and serum glutathione peroxidase enzyme (GPX, as a marker of antioxidant enzyme activity).

Afterwards, the rats were weighted and anesthetized using phenobarbital $(40 \mathrm{mg} / \mathrm{kg})$ then sacrificed by cervical dislocation followed by decapitation [18]. The whole brain was removed by careful rapid dissection and quickly removed outside the skull and thoroughly washed with isotonic saline. The harvested brain was immediately frozen at -80 until homogenized for measuringthe brain tissue content of $A \beta$ and tau proteins (as markers of neurodegenerative changes) and acetyle choline esterase (as a marker of loss of integrity of cholinergic neurons activity in the brain).

\section{Behavioral study:}

$Y$-maze spontaneous alternation test: Y-maze test was performed as previously described by Wall and Messier [19]. The maze was made of painted wood (to eliminate the spatial orientation visual cues) and has 3 identical arms, $40 \mathrm{~cm}$ long, $35 \mathrm{~cm}$ high and $12 \mathrm{~cm}$ wide, positioned at equal angles and labeled A, B, and C. The rats were placed at the end of arm A and allowed to move freely through the maze during a 5 minute-timed session. Spontaneous alternation was visually monitored to observe the pattern of rat entry into the maze's arms. Arm entry was considered to be complete when the hind paws of the rat have been entirety inside that arm. Alternation was defined as successive entries into the three arms on overlapping triplet set (i.e., $\mathrm{ABC}, \mathrm{BCA}$... ).
Assessment of spatial working memory: In this study, the following spatial working memoryindicator parameters were assessed using the Ymaze spontaneous alternation test $[17,19]$.

\section{1- The number of Total Arm Entries (TAE).}

2- Spontaneous Alternation Performances (SAP) score (defined as successive entries into the three arms on overlapping triplet set (i.e., ABC, BCA, etc...).

3- Spontaneous Alternation Percentage (SAP \%) (the percentage of the correct triad) was calculated using the following equation: $\operatorname{SAP}(\%)=$ [(number of alternations)/(total arm entries 2)] X 100.

\section{Biochemical analysis:}

1- A $\beta$ in the brain tissue ( $\mathrm{pg} / \mathrm{mg}$ protein) was measured by RT.qPCR [20]

2- Tau protein in the brain tissue (ng/mg protein) was measured by RT.qPCR [21].

3- Acetyl choline in the brain tissue ( molmg protein): Was measured by the colorimetric method using a choline/acetylcholine assay kit (Acetyl choline, BioVision Inc., California, USA) [22].

4- Serum GPX (U/ml) was measured colorimetrically using a commercial assay kit (Biodiagnostic, Egypt) [23].

5- Serum MDA ( $\mathrm{nmol} / \mathrm{ml}$ ): (Was measured by thiobarbituric acid colorimetric method using MDA assay kit (MDA, Cell Biolabs, USA, Catalog No., STA-330) [24].

\section{Statistical analysis:}

In the present study, the data were analyzed using the statistical package for social sciences program, version 23 (SPSS Inc., Chicago, Illinois, USA). The results were expressed as mean \pm SD. The significance of differences between groups was determined by one-way analysis of variance (ANOVA) followed by post-hoc Tukey test. $p$ values d0.05 were considered statistically significant [25].

\section{Results}

\section{Behavioral results:}

Assessment of spatial working memory showed that $\mathrm{SAP} \%$, at Y-maze test, in AD group was 54.00 \pm 9.00 which was statistically significant lower $(p<0.001)$ than the corresponding mean value in the control group $(72.00 \pm 16.00 \%)$. On the other hand the mean value of SAP\% in TQ/AD group 
was $71.00 \pm 15.00 \%$ which was statistically significant higher $(p<0.001)$ than that of AD group Fig.

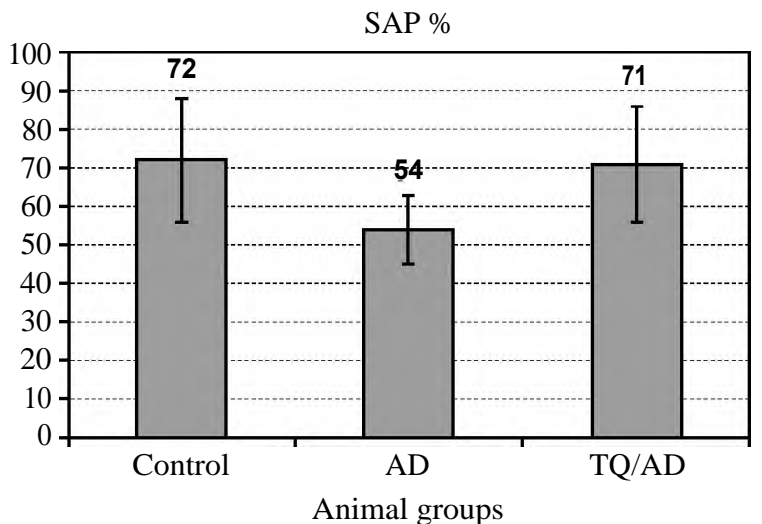

Fig. (1): The mean \pm SD of SPA\% in $\mathrm{nmol} / \mathrm{ml}$ in all studied groups of rats.

\section{Biochemical results:}

The mean value of $A \beta$ in the brain tissue in $A D$ group was $11.4 \pm 2.8 \mathrm{pg} / \mathrm{mg}$ protein which was statistically significant higher $(p<0.005)$ than the corresponding value in the control group $(1.7 \pm 0.3)$. On the other hand, the mean value of tau protein in TQ/AD group was $4.5 \pm 1.4$ which was significant lower $(p<0.005)$ than AD group (Table 1) and Fig.

Table (1): Biochemical parameters in control, $\mathrm{AD}$ and TQ/AD groups.

\begin{tabular}{llll}
\hline & Control & \multicolumn{1}{c}{ AD } & TQ/AD \\
\hline $\mathrm{A} \beta(\mathrm{pg} / \mathrm{mg})$ & $1.7 \pm 0.3$ & $11.4 \pm 2.8 \mathrm{a}$ & $4.5 \pm 1.4 \mathbf{a b}$ \\
tau protein $(\mathrm{ng} / \mathrm{mg})$ & $1.1 \pm 0.2$ & $11.5 \pm 2.2 \mathrm{a}$ & $5.4 \pm 1.2^{\mathbf{a b}}$ \\
Acetyl choline $(\mu \mathrm{mol} / \mathrm{mg})$ & $40.7 \pm 5.2$ & $18.9 \pm 5.5 \mathrm{a}$ & $32.4 \pm 4.2 \mathbf{a b}$ \\
Serum GpX $(\mathrm{U} / \mathrm{ml})$ & $101.0 \pm 21.3$ & $53.3 \pm 13.8 \mathrm{a}$ & $91.4 \pm 16.0^{\mathbf{a b}}$ \\
Serum MDA $(\mathrm{nmol} / \mathrm{ml})$ & $8.7 \pm 1.8$ & $55.2 \pm 9.5 \mathrm{a}$ & $21.2 \pm 4.9^{\mathbf{a b}}$ \\
\hline
\end{tabular}

Values are expressed as mean \pm SD $(n=10)$.

Statistical analysis was carried out by One-way ANOVA followed by Tukey's intergroup multiple comparison test.

AD :

TQ/AD

a

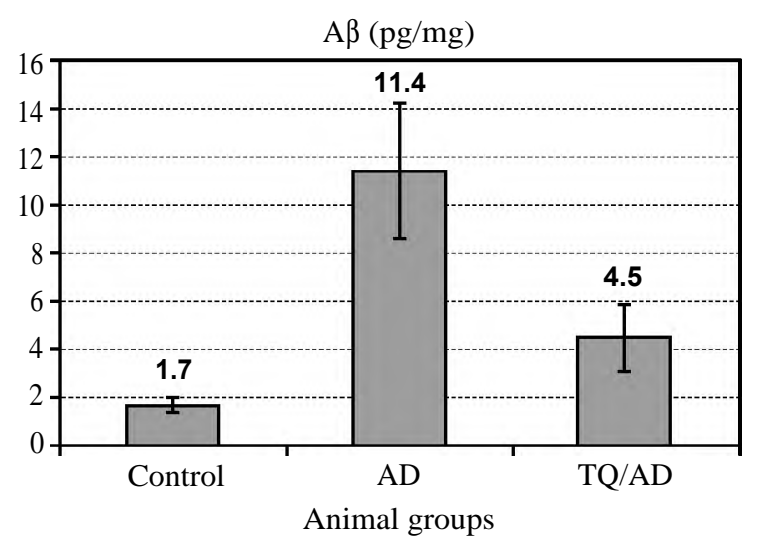

Fig. (2): The mean $\pm \mathrm{SD}$ of $\mathrm{A} \beta$ in $\mathrm{pg} / \mathrm{mg}$ in the brain homogenate in all studied groups of rats.
The mean value of tau protein in the brain tissue in $\mathrm{AD}$ group was $11.5 \pm 2.2 \mathrm{ng} / \mathrm{mg}$ protein, which was statistically significant higher $(p<0.005)$ than the corresponding value in the control group $(1.1 \pm$ 0.2 ). On the other hand, the mean value of tau protein in TQ/AD group was $5.4 \pm 1.2$ which was significant lower $(p<0.005)$ than $\mathrm{AD}$ group (Table 1) and Fig. (3).

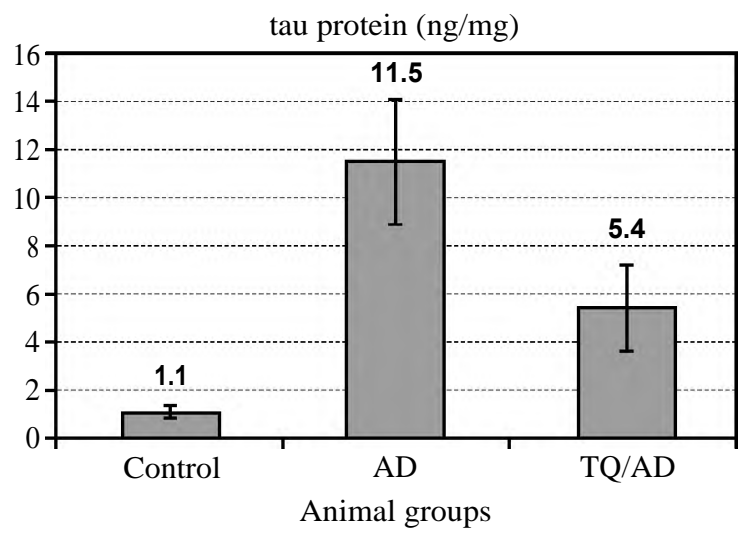

Fig. (3): The mean \pm SD of tau protein in $\mathrm{ng} / \mathrm{mg}$ in the brain homogenate in all studied groups of rats.

The mean value of acetyl choline in the brain tissue in $\mathrm{AD}$ group was $18.9 \pm 5.5 \mathrm{momg}$ protein which was statistically significant higher $(p<0.005)$ than the corresponding value in the control group $(40.7 \pm 5.2)$. On the other hand, the mean value of tau protein in TQ/AD group was $32.4 \pm 4.2$ which was significant lower $(p<0.005)$ than $\mathrm{AD}$ group (Table 1) and Fig. (4).

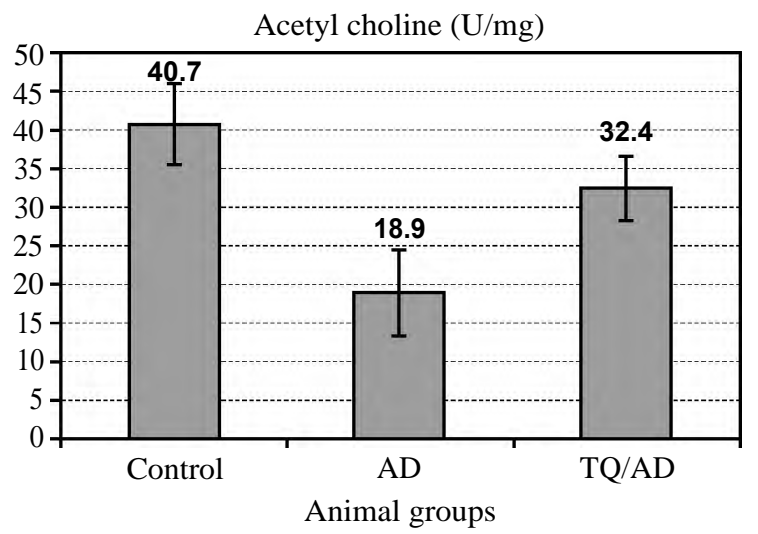

Fig. (4): The mean \pm SD of acetylecholine in $\mathbf{m o l} / \mathrm{mg}$ in the brain homogenate in all studied groups of rats.

The mean value of serum GPX in the brain tissue in $\mathrm{AD}$ group was $53.3 \pm 13.8 \mathrm{U} / \mathrm{ml}$ which was statistically significant higher $(p<0.005)$ than the corresponding value in the control group (101.0 \pm 21.3). On the other hand, the mean value of tau protein in $\mathrm{TQ} / \mathrm{AD}$ group was $91.4 \pm 16.0$ which was significant lower $(p<0.005)$ than AD group (Table 1) and Fig. (5). 


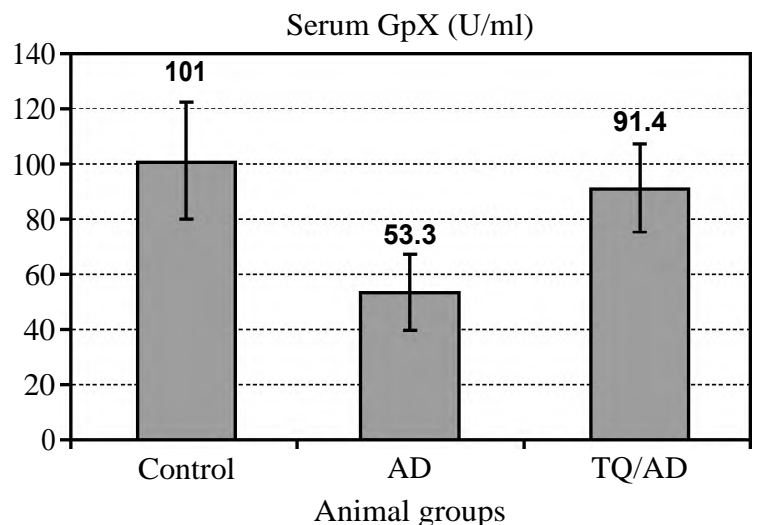

Fig. (5): The mean $\pm \mathrm{SD}$ of $\mathrm{GpX}$ in $\mathrm{u} / \mathrm{ml}$ in all studied groups of rats.

The mean value of serum MDA in the brain tissue in $\mathrm{AD}$ group was $55.2 \pm 9.5 \mathrm{nmol} / \mathrm{ml}$ which was statistically significant higher $(p<0.005)$ than the corresponding value in the control group (8.7 \pm 1.8 ). On the other hand, the mean value of MDA in TQ/AD group was $21.2 \pm 4.9$ which was significant lower $(p<0.005)$ than $\mathrm{AD}$ group (Table 1) and Fig. (6).

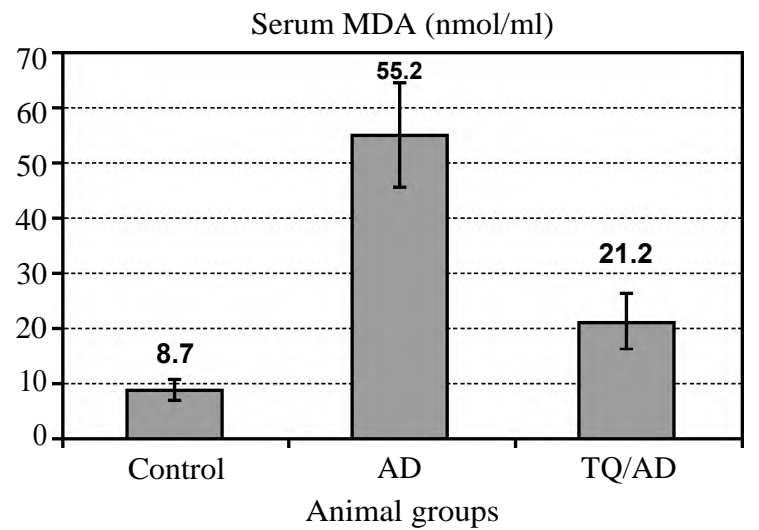

Fig. (6): The mean \pm SD of MDA in $\mathrm{nmol} / \mathrm{ml}$ in all studied groups of rats.

\section{Discussion}

Alzheimer's Disease (AD) is a major devastating neurodegenerative disorder of brain that, to date, has no settled underlying mechanism(s) and its successful treatment remains one of the big challenges in the field of neurology. Hence it continues to be associated with a high rate of morbidity and mortality. AD exhibits two hallmark brain lesions the Neurofibrillary Tangles (NFTs) and senile plaques) [26] . NFTs are formed by intraneuronal accumulation of paired helical filaments composed of abnormally hyperphosphorylated tau protein and senile plaques contain amyloid- $\beta$ peptide $(A \beta)$ [26].

The results of this study showed a significant decrease in Spontaneous Alternation Percentage
(SAP\%) in AD group compared to the control group. This finding was in agreement with Pagnier et al., [27] who found a decrease in alteration behavior at Y-maze in an AD mice model. Also, this finding was in agreement with Abulfadl et al., [28], who found a decrease in the step through latency in the passive avoidance test of AD rat model. The above-mentioned decline in behavior alteration performance indicate a deterioration of the spatial working memory of $\mathrm{AD}$ rats that is mostly attributed to the neurological cell damage and synaptic dysfunction encountered in rats' brain with $\mathrm{AD}$ [29].

On the other hand, TQ/AD group showed a significant improvement in SAP\% when compared to AD group. Interestingly, this improvement of the behavioral performance reflected mostly preserved memory and learning in TQ/AD group. In agreement with our results, Bargi et al., [30] and Dalli et al., [31] reported that TQ had the capability to reduce memory impairment and improve learning in passive avoidance test and in Moris Water Maize (MWM) test in rat models of AD. They have attributed their results to the neuroprotective role of TQ in AD. They have correlated this neuroprotection to the ability of TQ in decreasing A $\beta$ level in brain tissue and reducing $A \beta$-induced inflammatory mediators in the hippocampus of these animals and subsequently decreasing the cytokine-induced suppression of the Long Term Potentiation (LTP).

Biologically, the hippocampus is considered to be the most sensitive area in the brain to the deleterious effect of inflammatory mediators [32]. This is probably due to enrichment of the hippocampus with cytokine receptors [30]. These beneficial roles of TQ in improving the behavioral performance in $\mathrm{AD}$ is presumably due to its potent anti-inflammatory effect [33]

Our results showed an increase of $A \beta$ level in the brain of Alcl3-induced $\mathrm{AD}$ group compared to the control one. This result was in agreement with Wang et al., [34] who conduct an experimental meta analysis in which aluminum administration was found to increase $A \beta$ levels in the brain of experimental animals.

For decades, it was reported that the extracellular accumulation of senile plaques in the brain is one of hypothesis in the development of $\mathrm{AD}$. $\mathrm{A} \beta$ is the major component of these senile plaques and it is made from $\beta$-plated sheet fibrils and neuritis of destructed synapses and dendrites and invading astrocytes and inflammatory cell infiltration. $A \beta$ is released from a sequential proteolytic 
cleavage of a large, $\sim 770$ amino acids, type I transmembrane glycoprotein called Amyloid Precursor Protein (APP) which is abundant in the central neurons and to a lesser extent by the glial cells [35]

Proteolytic processing of APP has two different pathways. The first pathway is the non-amyloidogenic pathway that involves APP cleavage by $\alpha$ secretase enzyme and results in the release of extracellular soluble APP (sAPP $\alpha)$ and a transmembrane C83 (also calledcarboxyterminal fragments alpha $(\mathrm{CTF} \alpha)$ part. CTF $\alpha$ is further cleaved by $\gamma$ secretase, yielding a protein fragment called $\mathrm{p} 3$ and Amino-terminal Intracellular Domain (AICD). sAPP $\alpha$ residue on the other hand, is a non-harmful protein that is thought to have a neuroprotective role through the suppression of abnormally elevated intracellular $\mathrm{Ca}$ in neurons via reducing the glutamate-induced NMDA currents [36]

The second pathway is the amyloidogenic pathway in which APP is cleaved by $\beta$ secretase resulting in a sAPP $\beta$ and C99 protein residue (also called CTF $\beta$ ). The later is further cleaved by $\gamma$ secretase forming the non-soluble $A \beta$ [37]. $\gamma$ secretase has an imprecise cleavage point, yielding isoforms of $A \beta$ of different amino acid length of which $A \beta 40$ and $A \beta 42$ are the most relevant [35]

Numerous previous studies have adopted $\mathrm{AlCl} 3-$ induced AD models in mice [38], rats [39], rabbits [40] as well as in cultured cells [41]. These studies documented an increase in A $\beta$ level and conformational changes of $A \beta$ that enhanced its aggregation in a fashion that mimics the structure picture of $\mathrm{AD}$ in humans.

In the clinical field, studies on the effect of $\mathrm{Al}$ on $A \beta$ in human are scanty in comparison to those in animals. Yet, there are number of epidemiological studies correlated the increase of environmental $\mathrm{Al}$ level to $\mathrm{AD}$ [41-43]. Al is known to exert a neurotoxic effect through vascular, inflammatory, oxidative, metabolic and many other proposed mechanisms that ultimately result in cellular brain damage $[41,44]$

The results of our study showed a significant decrease in $\mathrm{A} \beta$ level in brain homogenate of $\mathrm{TQ} / \mathrm{AD}$ group when compared to $\mathrm{AD}$ group. These results were concomitant with Abulfadl et al., [28] who found that TQ decreased $A \beta$ level in brain tissue upon histological examination.

In addition, in vitro studies have found that TQ significantly decreased the $A \beta$ neurotoxicity and aggregation when it was applied simultaneously with this protein residue onto cultured hippocumpal neuronal cells in a dose dependant manner $[45,46]$ These in vitro studies have attributed this beneficial effect of TQ in inhibiting in vitro A $\beta$ neurotoxicity to its antioxidant effect, where it could scavenge ROS released in the cultured media.

Another protein that is related to $\mathrm{AD}$, is microtubules-associated protein (tau protein) that is deposited intracellularly in the central neurons in cases of $\mathrm{AD}$ and causes disturbance in axonal transport and in Microtubules (MT) assembly. Much evidence have documented that the clinical presentation and severity of AD almost always correlates with tau protein and NFT's formation more than the correlation with A $\beta$ plaques [47].

Functionally, tau protein gives support to the intraneuronal MT and controls the spacing between them [48] and maintains the assembling of these MT and the transport and communication systems of neurons [49]. This transport system involves mainly two proteins. The first is called kinesin which is the motor protein responsible for the anterograde transport, from the center to the periphery, of different cellular vesicles inside the neurons. The second is called dynein is the motor protein responsible for the opposite, retrograde, transport of these vesicles [50]. The net effect is redistribution and accumulation of essential cell components towards the MT organizing center leavening the cell periphery deprived of energy and vulnerable to oxidative stress [51].

In $\mathrm{AD}$, the high concentration of tau can inhibit kinesin action by competing for its binding site on MT [52]. This inhibition of kinesin leads to a marked slowing of the anterograde movement of the cellular components. Contrary, the retrograde movement is unaffected [53]. Furthermore, Tau affinity to the microtubules is affected by the rate and extent of its phosphorylation. The phosphorylated tau has low affinity towards MT and it has the ability to sequester other tau proteins to form aggregation [54]. Tau phosphorylation is under the influence of phosphatases and kinases enzymes, where in $\mathrm{AD}$ the later becomes more prominent [50]. This is because in $\mathrm{AD}, \mathrm{A} \beta$ causes the hyperphosphorylation of tau through activation of glycogen synthase kinase $3 \beta($ Gsk $3 \beta)$ and cyclin dependent kinase 5 (Cdk5) which accelerate the NFT's [55]

Once hyperphosphorylated some conformational changes occur in tau, where they are rapidly polymerized into NFT's that impair axoplasmic flow and lead to slow progressive retrograde degeneration and loss of connectivity of the affected 
neurons and causes cell death [56]. After phosphorylation, tau dissociated from MT, thus they collapse and the hyperphosphorylated tau form cross linking structures called NFT's which aggregate and induces oxidative stress inside the neurons $[41,57]$. This is of a great value since the oxidative stress exert extravagant cellular damage in the presence of an abnormally increased tau level [51]

Here it is worth mentioning that the tau neurotoxicity is correlated with its phosphorylation rather than with its deposition in NFT's [58]. This is based on previous experiments that showed that suppressing tau expression preserved the neural brain cells despite the continued accumulation of NFT's [59]

In this study, there was a significant decrease of the elevated tau level in TQ/AD group when compared with AD group. This encountered neuroprotection role of TQ is not only due to its ability to decrease tau level, but also due to reduction of oxidative stress as was confirmed in this work upon measuring GPx level. These antioxidant effects of TQ that may indirectly decreased tau phosphorylation and in turn preserve the microtubules from collapse.

In this study, acytyl choline level was significantly decreased in the brain of AD group compared with the control group. This was in line with Yassin et al., [14] who found that acetyl choline level decreased in Alcl3-induced AD of rats. Also this decline of acetyl choline was reported by Pákáski and Kálmán [60]. Actually, acetylcholine is one of the major excitatory neurotransmitters in the brain. Acetylcholine, cholinergic receptors and cholinergic neurons forming the cholinergic system. This system has an important role in cerebral perfusion, vasodilatation as well as the integrity of the blood brain barrier [61]

It was reported that acetylcholine is highly linked to AD. Cholinergic abnormalities are reported to exist as early as the prodromal phase of this disease [62]. At late stage, up to $75 \%$ of cholinergic neurons are lost [63]. The deterioration of the cholinergic system is one the hypothesis that is adopted to explain pathophysiology of AD. Previous studies have found that there was a decrease of choline acetyltransferase activity that is responsible for formation of Ach in the cytosol of the cholinergic nerve terminals, cholinergic neurons acetylcholine as well as cholinergic receptors in $\mathrm{AD}$ of humans and other species [64]. It was found that cholinergic depletion increased A R deposition [65] and tau phosphorelation and pro-inflammatory cytokines formation [66].
Therefore, restoration of cholinergic functions in $\mathrm{AD}$ might improve the pathophysiological aspects and hence the clinical presentation as well [62]. This is the basis of the anti-cholinestrase enzyme inhibitors group of drugs like rivastigmine and donazepil in management of $\mathrm{AD}$ via increasing Ach level. In line with basis of management, our results revealed a significant increase in acetylcholine level in the brain tissue of TQ/AD group compared with $\mathrm{AD}$ group. In support to our results, Jukic et al., [67] have found that TQ possessed anticholinestrase activity.

Actually, the exact mechanism(s) behind AD are unsettled yet. Nevertheless, there are accumulating evidence that the pathogenesis maybe related to the release of Reactive Oxygen Species (ROS), with intermingling oxidative stress in the brain tissue, particularly in the hippocampal region [68] Previous studies on the chronological events of AD showed that oxidative stress might be the earliest event in AD even preceding A R aggregation. This oxidative stress is correlated to the incidence, duration, severity and the mortality rate of $\mathrm{AD}$ [68] Moreover, the oxidative stress is accused for direct neuronal apoptosis [69], enhancement of $A D$ aggregation [70] as well as tau phosphorylation [71]

The mechanism beyond the harmful effects of oxidative stress on the brain tissue in $\mathrm{AD}$ is due to over production of ROS. These species are reported to cause peroxidation of polyunsaturated fatty acids in the cell membrane of the brain cells resulting in formation of toxic byproduct metabolites such as MDA [72]. Consequently, in this study, MDA was measured in brain tissue of rats and it displayed a high level in AD group.

Actually, redox imbalance between high oxidants and low antioxidant level in the brain tissue represents a hallmark of $\mathrm{AD}$ [69]. This redox imbalance was evident in this work, where not only there was an increase of MDA level, but also there was a decrease in GPx level in the brain tissue of AD group compared to the control group. Upon comparing TQ/AD and AD groups, the results revealed a decrease in the MDA accompanied with an increase in GPx level in the former group. Our results were concomitant with the findings of numerous previous studies that reported a significant improvement of oxidative stress MDA, Supraoxide Dismutase (SOD), catalase and reduced glutathione (GSH) on TQ administration [30]. Furthermore, Alhebshi et al., [47] found that TQ administration increased cell survival rate of hippocumpal cells and restored the redox balance in an invitro study in which cultured rat hippocumpal 
and cortical neurons displayed A R aggregation similar to what is encountered in AD disease upon their incubation with human AR 1-42. This restoration of the redox balance upon TQ administration could be attributed to its anti-oxidant property [73] This crucial antioxidant role of TQ, encountered in our study, provided a promising prophylactic potential against $\mathrm{AD}$.

\section{Conclusion:}

From the obtained data of this study, it could be concluded that TQ has a neuroprotective role in experimental $\mathrm{AD}$ model. This is mostly related to its antioxidant role and its ability to increase Ach in the brain tissue of rats. This may be an impetus for further clinical studies.

\section{Conflicting interests:}

The author(s) declared no conflict of interest with respect to the research, authorship, and/or publication of this article.

\section{References}

1- BABRI S., MOHADDES G., FEIZI I., MOHAMMADNIA A., NIAPOUR A., ALIHEMMATI A. and AMANI M.: Effect of troxerutin on synaptic plasticity of hippocampal dentate gyrus neurons in a $\beta$-amyloid model of Alzheimer' s disease: An electrophysiological study. European Journal of Pharmacology, 732: 19-25, 2014.

2- VAN CAUWENBERGHE C., VAN BROECKHOVEN C. and SLEEGERS K.: The genetic landscape of Alzheimer disease: Clinical implications and perspectives. Genetics in Medicine, 18 (5): 421, 2016.

3- PLASSMAN B.L., LANGA K.M., FISHER G.G., HEERINGA S.G., WEIR D.R., OFSTEDAL M.B. and STEFFENS D.C.: Prevalence of dementia in the United States: The aging, demographics, and memory study. Neuroepidemiology, 29 (1-2): 125-32, 2007.

4- KOROLEV I.O.: Alzheimer's disease: A clinical and basic science review. Medical Student Research Journal, 4: 24 33, 2014.

5- IMBIMBO B.P., LOMBARD J. and POMARA N.: Pathophysiology of Alzheimer's disease. Neuroimaging Clinics, 15 (4): 727-53, 2005.

6- LAKSHMI B.V.S., SUDHAKAR M. and PRAKASH K.S Protective effect of selenium against aluminum chlorideinduced Alzheimer's disease: Behavioral and biochemical alterations in rats. Biological trace element research, 165 (1): 67-74, 2015.

7- QUERFURTH H.W. and LaFERLA F.M.: Alzheimer's disease. N. Engl. J. Med., 362: 329-44, 2010.

8- MORRISON A.S. and LYKETSOS C.: The pathophysiology of Alzheimer's disease and directions in treatment. Adv. Stud. Nurs., 3 (8): 256-70, 2005.

9- RASCHETTI R., ALBANESE E., VANACORE N. and MAGGINI M.: Cholinesterase inhibitors in mild cognitive impairment: A systematic review of randomised trials. PLoS medicine, 4 (11): e338, 2007.

10- BAI T., LIAN L.H., WU Y.L., WAN Y. and NAN J.X.: Thymoquinone attenuates liver fibrosis via PI3Kand TLR4 signaling pathways in activated hepatic stellate cells. Int. Immunophar.-Macol., 15: 275-81, 2013.

11- SHRIVASTAVA R.M., AGRAWAL R.C., PARVEEN Z.J.: A review on therapeutic applications of Nigella sativa. J. Chem. Chem. Sci., 1: 241-8, 2011.

12- RADAD K., HASSANEIN K., AL-SHRAIM M., MOLDZIO R. and RAUSCH W.D.: Thymoquinone ameliorates lead-induced brain damage in Sprague Dawley rats. Experimental and Toxicologic Pathology, 66 (1): 137, 2014.

13- ISMAIL N., ISMAIL M., MAZLAN M., LATIFF L.A., IMAM M.U., IQBAL S. and CHAN K.W.: Thymoquinone prevents $P$-amyloid neurotoxicity in primary cultured cerebellar granule neurons. Cellular and molecular neurobiology, 33 (8): 1159-69, 2013.

14- YASSIN N., EL-SHENAWY S., MAHDY K.A., GOUDA N., MARRIE A., FARRAG A. and IBRAHIM B.M.: Effect of Boswellia serrata on Alzheimer's disease induced in rats. J. Arab Soc. Med. Res., 8: pp. 1-11, 2013.

15- GHONEIM F.M., KHALAF H.A., ELSAMANOUDY A.Z., EL-KHAIR S.M.A., HELALY A.M., MAHMOUD E.H.M. and ELSHAFEY S.H.: Protective effect of chronic caffeine intake on gene expression of brain derived neurotrophic factor signaling and the immunoreactivity of glial fibrillary acidic protein and Ki-67 in Alzheimer's disease. International journal of clinical and experimental pathology, 8 (7): 7710, 2015.

16-KRASOVSKI 1 G.N., VASUKOVICH L.Y. and CHARIEV O.G.: Experimental study of biological effects of lead and aluminum following oral administration. Environ Health Perspect, 30: 47-51, 1979.

17- PAUL C.M., MAGDA G. and ABEL S.: Spatial memory: Theoretical basis and comparative review on experimental methods in rodents. Behavioural brain research, 203 (2): pp. 151-64, 2009.

18- ZHAO H., WANG L., CHEN L., ZHANG J., SUN W., SALVI R.J., HUANG Y.N., WANG M. and CHEN L.: Temporary conductive hearing loss in early life impairs spatial memory of rats in adulthood. Brain and Behavior, 8 (7): p. e01004, 2018.

19- WALL P.M. and MESSIER C.: Infralimbic kappa opioid and muscarinic M1 receptor interactions in the concurrent modulation of anxiety and memory. Psychopharmacology, 160 (3): pp. 233-44, 2002.

20- ZHAO Z., HO L., WANG J., QIN W., FESTA E.D., MOBBS C. and PASINETTI G.M.: Connective tissue growth factor (CTGF) expression in the brain is a downstream effector of insulin resistance-associated promotion of Alzheimer's disease P-amyloid neuropathology. The FASEB Journal, 19 (14): 2081-2, 2005.

21- DWIVEDI S., NAGARAJAN R., HANIF K., SIDDIQUI H.H., NATH C. and SHUKLA R.: Standardized extract of Bacopa monniera attenuates okadaic acid induced 
memory dysfunction in rats: Effect on Nrf2 pathway. Evidence-Based Complementary and Alternative Medicine, 2013.

22- OSWALD C., SMITS S.H., HÖING M., SOHN-BÖSSER L., DUPONT L., Le RUDULIER D., SCHMITT L. and BREMER E.: Crystal structures of the choline / acetylcholine substrate-binding protein ChoX from Sinorhizobium meliloti in the liganded and unliganded-closed states. Journal of Biological Chemistry, 283 (47): pp. 32848-59, 2008.

23- FLOHÉ L. and GÜNZLER, W.A.: Assays of glutathione peroxidase. In Methods in enzymology, 105: 114-21, Academic Press, 1984.

24- OHKAWA H., OHISHI W. and YAGI K.: Assay for lipid peroxides in animal tissues by thiobarbituric acid reaction. Biochem., 95: 351-8, 1979.

25- PETRIE A. and SABIN C.: In: Sugden M and Moore K "Medical statistics at a glance". 2 nd ed, Blackwell Publishing Ltd., USA, pp. 55-6, 2005.

26- HENRY M.S., PASSMORE A.P., TODD S., McGUINNESS B., CRAIG D. and JOHNSTON J.A.: The development of effective biomarkers for Alzheimer's disease: A review. Int. J. Geriatr. Psychiatry, 28 (4): 331-40, 2013.

27- PAGNIER G.J., KASTANENKA K.V., SOHN M., CHOI S., CHOI S.H., SOH H. and BACSKAI B.J.: Novel botanical drug DA-9803 prevents deficits in Alzheimer's mouse models. Alzheimer's Research \& Therapy, 10 (1): p. 11,2018

28- ABULFADL Y.S., EL-MARAGHY N.N., AHMED A.E., NOFAL S., ABDEL-MOTTALEB Y. and BADARY O.A.: Thymoquinone alleviates the experimentally induced Alzheimer's disease inflammation by modulation of TLRs signaling. Human \& Experimental Toxicology, 37 (10): pp. 1092-104, 2018.

29- OAKLEY H., COLE S.L., LOGAN S., MAUS E., SHAO P., CRAFT J., GUILLOZET-BONGAARTS A., OHNO M., DISTERHOFT J., VAN ELDIK L. and BERRY R.: Intraneuronal 3 -amyloid aggregates, neurodegeneration, and neuron loss in transgenic mice with five familial Alzheimer's disease mutations: Potential factors in amyloid plaque formation. Journal of Neuroscience, 26 (40): pp. 10129-40, 2006.

30- BARGI R., ASGHARZADEH F., BEHESHTI F., HOSSEINI M., SADEGHNIA H.R. and KHAZAEI M.: The effects of thymoquinone on hippocampal cytokine level, brain oxidative stress status and memory deficits induced by lipopolysaccharide in rats. Cytokine, 96, pp. 173-84, 2017.

31- DALLI T., BEKER M., TERZIOGLU-USAK S., AKBAS F. and ELIBOL B.: Thymoquinone activates MAPK pathway in hippocampus of streptozotocin-treated rat model. Biomedicine \& Pharmacotherapy, 99, pp. 391-401, 2018.

32- BARRIENTOS R.M., HIGGINS E.A., BIEDENKAPP J.C., SPRUNGER D.B., WRIGHT-HARDESTY K.J., WATKINS L.R., RUDY J.W. and MAIER S.F.: Peripheral infection and aging interact to impair hippocampal memory consolidation. Neurobiology of aging, 27 (5): pp. 723 32, 2006.
33- AMIN B. and HOSSEINZADEH H.: Black cumin (Nigella sativa) and its active constituent, thymoquinone: An overview on the analgesic and anti-inflammatory effects. Planta medica, 82 (01/02): pp. 8-16, 2016.

34- WANG Z., WEI X., YANG J., SUO J., CHEN J., LIU X. and ZHAO X.: Chronic exposure to aluminum and risk of Alzheimer's disease: A meta-analysis. Neuroscience letters, 610, pp. 200-6, 2016.

35- HAQUE R., UDDIN S.N. and HOSSAIN A.: Amyloid Beta (AR) and Oxidative Stress: Progression of Alzheimer's Disease. Adv. Biotech. \& Micro., 11 (1): 1-10, 2018.

36- KANDIMALLA R., VALLAMKONDU J., CORGIAT E.B. and GILL K.D.: Understanding Aspects of Aluminum Exposure in A lzheimer's Disease Development. Brain pathology, 26 (2): pp. 139-54, 2016.

37- CATRICALA S., TORTI M. and RICEVUTI G.: Alzheimer disease and platelets: How's that relevant. Immunity \& Ageing, 9 (1): p. 20, 2012.

38- PRATICÒ D., URYU K., SUNG S., TANG S., TROJANOWSKI J.Q. and LEE V.M.Y.: Aluminum modulates brain amyloidosis through oxidative stress in APP transgenic mice. The FASEB Journal, 16 (9): pp. 1138-40, 2002.

39- CHEN S.M., FAN C.C., CHIUE M.S., CHOU C., CHEN J.H. and HSEU R.S.: Hemodynamic and neuropathological analysis in rats with aluminum trichloride-induced Alzheimer's disease. PloS one, 8 (12): p. e82561, 2013.

40- PANAHI N., MAHMOUDIAN M., MORTAZAVI P. and HASHJIN G. S.: Effects of berberine on $\beta$-secretase activity in a rabbit model of Alzheimer's disease. Archives of medical science: AMS, 9 (1): p. 146, 2013.

41- KAWAHARA M., KATO M. and KURODA Y.: Effects of aluminum on the neurotoxicity of primary cultured neurons and on the aggregation of 3 -amyloid protein. Brain research bulletin, 55 (2): pp. 211-21, 2001.

42- ALTMANN P., CUNNINGHAM J., DHANESHA U., BALLARD M., THOMPSON J. and MARSH F.: Disturbance of cerebral function in people exposed to drinking water contaminated with aluminium sulphate: Retrospective study of the Camelford water incident. BMJ, 319 (7213): pp. 807-11, 1999.

43- RONDEAU V., COMMENGES D., JACQMIN-GADDA H. and DARTIGUES J.F.: Relation between aluminum concentrations in drinking water and Alzheimer's disease: An 8-year follow-up study. American Journal of Epidemiology, 152 (1): pp. 59-66, 2000.

44- EXLEY C.: Human exposure to aluminium. Environmental Science: Processes \& Impacts, 15 (10): pp. 1807-16, 2013.

45- KHAN A., VAIBHAV K., JAVED H., KHAN M.M., TABASSUM R., AHMED M.E., SRIVASTAVA P., KHUWAJA G., ISLAM F., SIDDIQUI M.S. and SHAFI M.M.: Attenuation of $A \beta$-induced neurotoxicity by thymoquinone via inhibition of mitochondrial dysfunction and oxidative stress. Molecular and cellular biochemistry, 369 (1-2): pp. 55-65, 2012.

46- ALHEBSHI A.H., GOTOH M. and SUZUKI I.: Thymoquinone protects cultured rat primary neurons against 
amyloid $\mathrm{P}$-induced neurotoxicity. Biochemical and biophysical research communications, 433 (4): pp. 362-7, 2013.

47- DELACOURTE A., SERGEANT N., WATTEZ A., MAURAGE C.A., LEBERT F., PASQUIER F. and DAVID J.P.: Tau aggregation in the hippocampal formation: An ageing or a pathological process? Experimental gerontology, 37 (10-11): pp. 1291-6, 2002.

48- WU X.L., PIÑA-CRESPO J., ZHANG Y.W., CHEN X.C. and XU H.X.: Tau-mediated neurodegeneration and potential implications in diagnosis and treatment of Alzheimer's disease. Chinese Medical Journal, 130 (24): p. 2978, 2017.

49- SAUNDERS J. and DONHAUSER Z.: A Functional Analysis of the Projection Domain of the Microtubule Associated Protein Tau Using Force Spectroscopy, 10364, 2013.

50- BALLATORE A.B. SMITH III, V.M. Y. LEE J.Q. TROJANOWSKI and K.R. BRUNDEN: "Microtubule stabilization" In: Michael S. Wolfe. "Developing Therapeutics for Alzheimer's Disease progress and challenges". 2nd ed. Elsevier, London, pp. 305-11, 2016.

51- STAMER K., VOGEL R., THIES E., MANDELKOW E. and MANDELKOW E.M.: Tau blocks traffic of organelles, neurofilaments, and APP vesicles in neurons and enhances oxidative stress. The Journal of cell biology, $156(6)$ : pp. 1051-63, 2002.

52- BULINSKI J.C., McGRAW T.E., GRUBER D., NGUYEN H.L. and SHEETZ M.P.: Overexpression of MAP4 inhibits organelle motility and trafficking in vivo. Journal of cell science, 110 (24): pp. 3055-64, 1997.

53- TRINCZEK B., EBNETH A., MANDELKOW E.M. and MANDELKOW E.: Tau regulates the attachment/ detachment but not the speed of motors in microtubule-dependent transport of single vesicles and organelles. Journal of cell science, 112 (14): pp. 2355-67, 1999.

54- IQBAL K., GONG C.X. and LIU F.: Microtubuleassociated protein tau as a therapeutic target in Alzheimer's disease. Expert opinion on therapeutic targets, 18 (3): pp. 307-18, 2014.

55- IQBAL K., DEL A., ALONSO C, CHEN S., CHOHAN C.O., et al.: Tau pathology in Alzheimer disease and other tauopathies. Biochimica et Biophysica Acta, 1739 (2-3): 198-210, 2005.

56- IQBAL K., LIU F., GONG C.X., ALONSO ADEL C. and GRUNDKE-IQBAL I.: Mechanisms of tau-induced neurodegeneration. Acta Neuropathol., 118 (1): 53-69, 2009.

57- GREEN K.N. and SCHREIBER S.S.: "Advances in Our Understanding of the Pathophysiology of Alzheimer's Disease". US Neurology, 6 (1): 22-31, 2010.

58- YOSHIYAMA Y., HIGUCHI M., ZHANG B., HUANG S.M., IWATA N., SAIDO T.C., MAEDA J., SUHARA T., TROJANOWSKI J.Q. and LEE V.M.Y.: Synapse loss and microglial activation precede tangles in a P301 S tauopathy mouse model. Neuron, 53 (3): pp. 337-51, 2007.

59- SANTACRUZ K., LEWIS J., SPIRES T., PAULSON J., KOTILINEK L., INGELSSON M., GUIMARAES A.,
DeTURE M., RAMSDEN M., McGOWAN E. and FORSTER C.: Tau suppression in a neurodegenerative mouse model improves memory function. Science, 309 (5733): pp. 476-81, 2005.

60- PÁKÁSKI M. and KÁLMÁN J.: Interactions between the amyloid and cholinergic mechanisms in Alzheimer's disease. Neurochemistry International, 53 (5): pp. 10311, 2008.

61- VAN BEEK A.H. and CLAASSEN J.A.: The cerebrovascular role of the cholinergic neural system in Alzheimer's disease. Behavioural brain research, 221 (2): pp. 537-42, 2011.

62- HAMPEL H., MESULAM M.M., CUELLO A.C., FARLOW M.R., GIACOBINI E., GROSSBERG G.T., KHACHATURIAN A.S., VERGALLO A., CAVEDO E., SNYDER P.J. and KHACHATURIAN Z.S.: The cholinergic system in the pathophysiology and treatment of Alzheimer's disease. Brain, 141 (7): pp. 1917-33, 2018.

63- DIVYA P.: "Brief overview on alzheimer`s disease with recent treatment." Asian Journal of Pharmaceutical Education and Research, 3, no. 4: (1-9), 2014.

64- TEAKTONG T., GRAHAM A.J., COURT J.A., PERRY R.H., JAROS E., JOHNSON M., HALL R. and PERRY E.K.: Nicotinic acetylcholine receptor immunohistochemistry in Alzheimer's disease and dementia with Lewy bodies: Differential neuronal and astroglial pathology. Journal of the neurological sciences, 225 (1-2): pp. 3949, 2004.

65- RAMOS-RODRIGUEZ J.J., PACHECO-HERRERO M., THYSSEN D., MURILLO-CARRETERO M.I., BERROCOSO E., SPIRES-JONES T.L., BACSKAI B.J. and GARCIA-ALLOZA M.: Rapid P-amyloid deposition and cognitive impairment after cholinergic denervation in APP/PS1 mice. Journal of Neuropathology \& Experimental Neurology, 72 (4): pp. 272-85, 2013.

66- FIELD R.H., GOSSEN A. and CUNNINGHAM C.: Prior pathology in the basal forebrain cholinergic system predisposes to inflammation-induced working memory deficits: Reconciling inflammatory and cholinergic hypotheses of delirium. Journal of Neuroscience, 32 (18): pp. 628894, 2012.

67- JUKIC M., POLITEO O., MAKSIMOVIC M., MILOS M. and MILOS M.: In vitro acetylcholinesterase inhibitory properties of thymol, carvacrol and their derivatives thymoquinone and thymohydroquinone. Phytotherapy Research, 21 (3): pp. 259-61, 2007.

68- CASTELLANI R.J., ZHU X., LEE H.G., SMITH M.A and PERRY G.: Molecular pathogenesis of Alzheimer's disease: Reductionist versus expansionist approaches. International Journal of Molecular Sciences, 10 (3): pp. 1386-406, 2009.

69- WEYDERT C.J. and CULLEN J.J.: Measurement of superoxide dismutase, catalase and glutathione peroxidase in cultured cells and tissue. Nature Protocols, 5 (1): p. $51,2010$.

70- ABE T., TOHGI H., ISOBE C., MURATA T. and SATO C.: Remarkable increase in the concentration of 8hydroxyguanosine in cerebrospinal fluid from patients with Alzheimer's disease. Journal of Neuroscience Research, 70 (3): pp. 447-50, 2012. 
71- PEREZ M., CUADROS R., SMITH M.A., PERRY G and AVILA J.: Phosphorylated, but not native, tau protein assembles following reaction with the lipid peroxidation product, 4-hydroxy-2-nonenal. Febs Letters, 486 (3): pp. 270-4, 2000.

72- CASADO Á., LÓPEZ-FERNÁNDEZ M.E., CASADO M.C. and De La TORRE R.: Lipid peroxidation and antioxidant enzyme activities in vascular and Alzheimer dementias. Neurochemical Research, 33 (3): pp. 450-8, 2008.

73- AL-MAJED A.A., AL-OMAR F.A. and NAGI M.N.: Neuroprotective effects of thymoquinone against transient forebrain ischemia in the rat hippocampus. European Journal of Pharmacology, 543 (1-3): pp. 40-7, 2006.

\section{تآثير الثيموكينون على نموذج يشبه مرض الزهايمر فئى الفئران

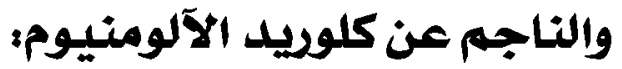 دراسة فسيولوجية عصبية وسلوكية الونيومية}

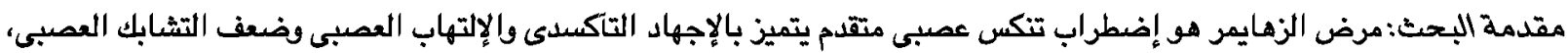

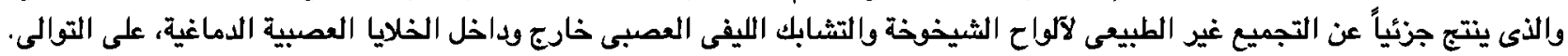

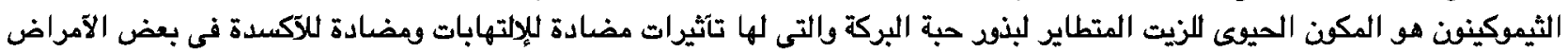

الهدف من البحث: تقييم إمكانات الحماية العصبية للثيموكينون على حالة الإجهاد التاكسدى المخ فى كلويد الآلومنيوم الناتج عن مرض الزهايمر فى الفتران الفئران.

مواد وطرق البحث: تم إستخدام ثلاثين ذكود من البالغين Sprague Dawley albino في هذه الدراسة ، تم تقسيمهم بشكل عشوائى إلى الى

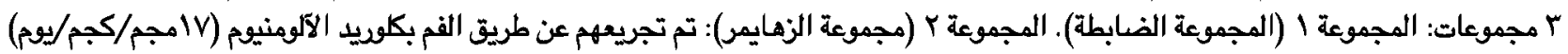

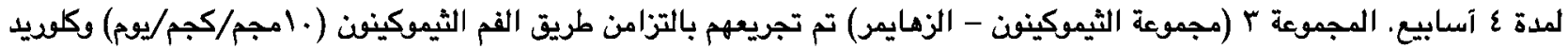

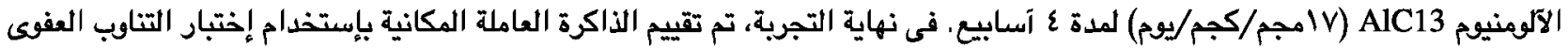

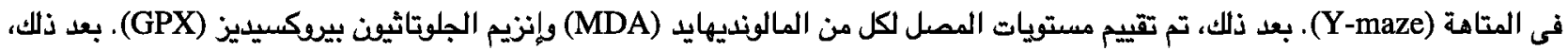

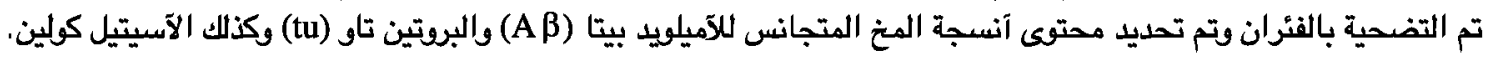

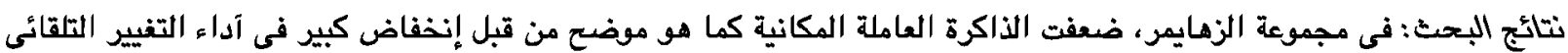

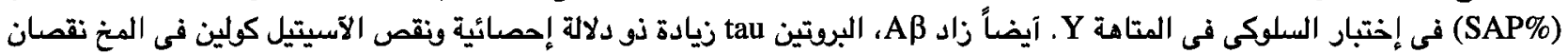

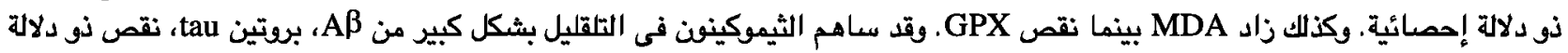

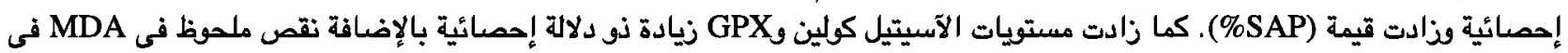

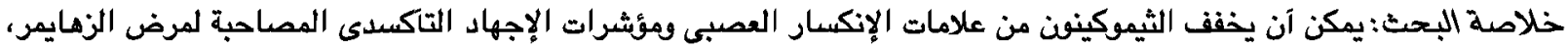

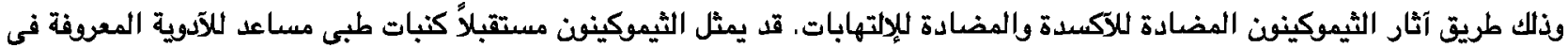

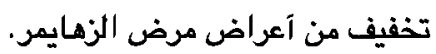

